\title{
Bioremediation of some chemical pollutants from Fayoum industrial area, Egypt
}

\author{
Khaled S.M. Foad ${ }^{1}$, Tharwat E.E. Radwan ${ }^{2}$, Mohamed S. Abd ELKrim ${ }^{1}$ and \\ Ashraf M.M. Essa ${ }^{2}$ \\ 1. Hydrobiology Department, National Institute of Oceanography and Fisheries \\ 2. Botany Department, Faculty of Science, Fayoum University \\ Corresponding author- Email: tsd00@fayoum.edu.eg
}

\begin{abstract}
Bioremediation of industrial wastewater using algae and bacteria is the main goal of this study. Samples were collected from industrial drain water of chemical industrial area (Kom Oshem, Fayoum, Egypt). The main microorganisms tested in this study were Chlorella vulgaris and Microccocus luteus. The growth of algae and bacteria on wastewater was estimated either singly or dually regarding their efficiency in biodegradation of pollutants of wastewater.

The results revealed that $C$. vulgaris and $M$. luteus caused a removal of nitrogen, phosphorus, potassium and magnesium from wastewater either singly or dually. Dual bio treatment achieved the best removal of pollutants from waste water. It reduced phosphorus by a percentage of $(78.71 \%)$, nitrate $(65.46 \%)$, potassium $(49.9 \%)$ and magnesium $(78.8 \%)$ within incubation period of 16 days.
\end{abstract}

Key words: Bioremediation, industrial wastewater, Chlorella vulgaris and Microccocus luteus.

\section{INTRODUCTION}

One of Egypt's environmental dangers is increasing of soil salinity and acidity. The fertility of soil is threatened by untreated industrial wastewater from many factories that lacked pollution control. Untreated wastewater affects farm lands, agricultural productivity and public health of human and animals. Shi (2009) indicated that these problems are one of the serious concerns among different environmental issues in the society and environmental laws.

Treatment of wastewater is mandatory to safe human beings and to protect our environment. Around the world, most of the wastewater treatment use chemical precipitation methods to remove phosphorus from wastewater, but this is not efficient and has many disadvantages. Mehta and Gaur (2005) mentioned that these techniques may be ineffective when concentration of metals in wastewater is in range between $10-100 \mathrm{mg}^{-1}$.

Economic and energy efficient nitrogen and phosphorus removal technology is the right way to overcome these problems by introducing an alternative biological method called bioremediation. It is a pollution control technology that uses biological systems to catalyze the degradation or transformation of various toxic chemicals to less harmful forms. It is less expensive than other technologies that are used for cleanup of wastewater (Vidali, 2001). Microalgae have generally fast growth, low cultivation cost, capability to assimilate wastes, and efficient in converting solar energy into biomass. Prabha et al. (2016) reported that, algae are important bioremediation agents and are already being used in wastewater treatment. Kshirsagar (2013) reported that, $C$. vulgaris have high removal capacity for nitrate and COD. Sharma and Khan (2013) suggested that growing algae in nutrient-rich sewage wastewater offers a new option of applying algae to manage the nutrient load and after phycoremediation. According to Chalivendra (2014), C. vulgaris taken from Pleasant Hill Lake were used as candidate species for 


\section{Khaled S.M. Foad et al.}

bioremediation of wastewater loaded with nitrogen $(\mathrm{N})$ in the form of nitrates and phosphorous (P) in the form of phosphates. Kaoutar et al. (2014) mentioned that, algae have an important role in controlling and bio-monitoring of organic pollutants in aquatic ecosystems. El-Sheekh et al. (2016) revealed that, both $C$. vulgaris and $C$. salina were highly efficient and having a potential to reduce $\mathrm{pH}$, total dissolved solids (TDS), biological oxygen demand (BOD), chemical oxygen demand (COD), nitrate, ammonia and phosphate.

According to Zhuang et al. (2010), halophilic microorganisms play an important role in the biological treatment of saline wastewater as decontamination pathways of organic contaminants, heavy metals and nutrients. Karigar et al. (2011) carried out an advanced bioprocess technology to reduce the toxicity of the pollutants and also to obtain novel useful substances by using enzymes from various microorganisms. Both algae and bacteria affect each other's physiology and metabolism, although bacteria have often been considered as mere contamination of algae cultures. However, in the last few years, the scenario has changed. Nowadays, algae-bacteria interactions are being seen as promising in biotechnology, as some recent studies have shown a positive effect of algae-bacteria interaction on algal growth, which is the essential step in algal biotechnology (Fuentes et al. 2016). Safonova et al. (2004) showed significant decrease in the content of the pollutants by using algal-bacterial associations. According to Hernandez (2006), combination treatment of microalgae with bacteria was capable of removing up to $72 \%$ of phosphorus from the wastewater. De-Bashan and Bashan (2010) used immobilized eukaryotic microalgae and several prokaryotic photosynthetic cyanobacteria in removing nutrients with the support of plant growth-promoting bacteria. Olguín (2012) suggested dual purpose in algae-bacteria relationship, the first: microalgae-bacteria-based systems for treating wastewater and the second is production of biofuels and chemical products.

So, the main goal of this study is to bio-remediate industrial wastewater of the chemical area of Kom Oshem, Fayoum, Egypt, using algae and bacteria either singly or dually.

\section{1- Growth medium and culture conditions 1.1- Growth medium for algae}

The stock algal cultures were received on agar slants obtained from the culture collection of algae in Botany Department, Faculty of Science, Cairo University. They were stored at room temperature $\left(27{ }^{\circ} \mathrm{C}\right)$ and illuminated at $\left(40-50 \mu \mathrm{E} \mathrm{m}^{-2} \mathrm{~s}^{-1}\right)$, then they were enriched in BG-11 medium (Allen and Stanier, 1968) and incubated for 8 days at $27{ }^{\circ} \mathrm{C}$ with illumination about (40$\left.50 \mu \mathrm{E} \mathrm{m} \mathrm{s}^{-1}\right)$. BG-11constituents were: $\mathrm{NaNO}_{3}\left(150 \mathrm{gL}^{-1}\right), \mathrm{K}_{2} \mathrm{HPO}_{4}\left(30 \mathrm{gL}^{-1}\right), \mathrm{MgSO}_{4} \cdot 7 \mathrm{H}_{2} \mathrm{O}$ $\left(75 \mathrm{gL}^{-1}\right), \mathrm{CaCl}_{2} \cdot 2 \mathrm{H}_{2} \mathrm{O}\left(36 \mathrm{gL}^{-1}\right)$, Citric Acid $\left(6 \mathrm{gL}^{-1}\right)$, Ferric Ammonium Citrate $\left(6 \mathrm{gL}^{-1}\right)$, EDTA (1 $\left.\mathrm{gL}^{-1}\right), \mathrm{Na}_{2} \mathrm{CO}_{3}\left(20 \mathrm{gL}^{-1}\right)$ and Trace Metal Solution. $\mathrm{pH}$ was approximately 7.5.

\section{2- Culture conditions for algae}

To obtain sufficient algal growth for use in wastewater treatment experiments, stock algal cultures were transferred and initially grown in $250 \mathrm{ml}$ Erlenmeyer flasks containing $100 \mathrm{ml}$ of BG-11 at $27 \pm 2{ }^{\circ} \mathrm{C}$ with cool white fluorescent lamps giving a continuous irradiance of $40-50$ $\mu \mathrm{molm}^{-2} \mathrm{sec}^{-1}$.

\section{3- Growth medium of bacteria}

Bacteria were grown in Luria Bertani (LB) medium (Sambrook et al., 1989), which consists of tryptone $\left(10.0 \mathrm{gL}^{-1}\right)$ and yeast extract $\left(5.0 \mathrm{gL}^{-1}\right)$. The solution was bought to $1 \mathrm{~L}$ by 


\section{Bioremediation of some chemical pollutants from Fayoum industrial area, Egypt}

adding distilled water then autoclaved at $121{ }^{\circ} \mathrm{C}$ for 15 minutes. The composition of Luria agar (LA) medium $\left(\mathrm{g} \mathrm{L}^{-1}\right)$ is the same LB media but the last one contains $20 \mathrm{~g} \mathrm{~L}^{-1}$ agar. The solution was supplemented with $1.5 \mathrm{~g} \mathrm{~L}^{-1} \mathrm{NaCl}$.The final $\mathrm{pH}$ was 7.5.

\section{4- Culture conditions of bacteria}

To obtain sufficient bacterial growth for use in wastewater treatment experiments, stock bacterial culture was incubated at $37{ }^{\circ} \mathrm{C}$ for 24 hours on an orbital shaker incubator operating at $120 \mathrm{rpm} \mathrm{min}^{-1}$. A total of $10 \mathrm{~mL}$ of the pure culture was centrifuged to pellet out the cells, washed twice with sterile physiological saline solution and the suspension was adjusted to optical density of 0.1 at $600 \mathrm{~nm}$ which is equivalent to a cell population of about $10^{6}$ cells mL $^{-1}$ on the McFarland standard. Bacterial suspension was stored in test tubes in a refrigerator at $4{ }^{\circ} \mathrm{C}$.

\section{Experimental setup}

\subsection{Experimental Setup of bio treatment of wastewater by algae}

Serial dilutions of wastewater of $0 \%, 20 \%, 40 \%, 60 \%, 80 \%$ and $100 \%$ were prepared in $250 \mathrm{~mL}$ Erlenmeyer flask containing the respective percentage of wastewater then completed to $100 \mathrm{~mL}$ by distilled water. The diluted wastewater autoclaved at $121^{\circ} \mathrm{C}$ for 20 minute, cooled then inoculated by equal volumes $(5 \mathrm{~mL})$ of each algal organism. All treatments were carried out in triplicates. Different treatments were subjected to four cool white fluorescent lamps (Philips F40T12/DX 40 Watts) giving a continuous irradiance of $40-50 \mu \mathrm{molm}^{-2} \mathrm{sec}^{-1}$, placed horizontally and parallel to the front and back of Erlenmeyer flasks till ending the experiment. The temperature was about $27 \pm 2{ }^{\circ} \mathrm{C}$.

\subsection{Experimental Setup of bio treatment of wastewater by bacteria}

Serial dilutions of wastewater were prepared as described above. Each dilution was prepared in $100 \mathrm{~mL}$ Erlenmeyer flasks containing the respective percentage ofwastewater, diluted to $50 \mathrm{~mL}$ volume, then autoclaved as mentioned above and inoculated by equal volumes $(1 \mathrm{~mL})$ of each bacterial organism. All treatments were carried out in triplicates, and incubated at $37 \pm 2{ }^{\circ} \mathrm{C}$ till ending the experiment.

\subsection{Experimental setup of dual bio treatment of wastewater by both of algae and bacteria}

Serial dilutions of wastewater were prepared as described above. Each dilution was prepared in $250 \mathrm{~mL}$ Erlenmeyer flasks containing the respective percentage of waste water, then it was diluted to $100 \mathrm{~mL}$ volume, then autoclaved and inoculated by equal volumes $(5 \mathrm{~mL})$ of $C$. vulgaris and $(1 \mathrm{~mL})$ of $M$. luteus. All treatments were carried out in triplicates then subjected at room temperature $27 \pm 2{ }^{\circ} \mathrm{C}$ with four cool white fluorescent lamps (Philips F40T12/DX 40 Watts) giving a continuous irradiance of (40-50 $\left.\mu \mathrm{molm}^{-2} \mathrm{sec}^{-1}\right)$ placed horizontally and parallel to the front and back of Erlenmeyer flasks till the experimental end.

\section{Growth estimation}

\subsection{Extraction and determination of photosynthetic pigments of algae}

The photosynthetic pigments chlorophyll-a were determined using the spectrophotometric method recommended by Metzner et al. (1965). A known volume of algal culture was homogenized in $85 \%$ aqueous acetone, then kept for 6 hours in a refrigerator. The homogenate was centrifuged and the supernatant was made up to a known volume with $85 \%$ acetone, then measured against a blank of pure 85\% acetone at three wave lengths: 452, 644 and 
Khaled S.M. Foad et al.

$663 \mathrm{~nm}$ using Perkin Elmer UV spectrophotometer, taking into consideration the dilution made. It was possible to determine the concentration of pigment fractions as $\mathrm{mg} / \mathrm{mL}$ using the following equations:

$\mathrm{C}_{\mathrm{a}}=10.3 \mathrm{E}_{663}-0.918 \mathrm{E}_{644}$

$\mathrm{C}_{\mathrm{b}}=19.7 \mathrm{E}_{644}-3.87 \mathrm{E}_{663}$

Carotenoid $=4.2 \mathrm{E}_{452}-\left(0.0264 \mathrm{C}_{\mathrm{a}}+0.426 \mathrm{C}_{\mathrm{b}}\right)$

Where, $\mathrm{C}_{\mathrm{a}}=$ Chlorophyll $\mathrm{a}, \mathrm{C}_{\mathrm{b}}=$ Chlorophyll $\mathrm{b}, \mathrm{C}_{\mathrm{x}+\mathrm{c}}=$ Total carotene

\subsection{Determination of algal cell counts}

Algal cell counts were performed using Haemocytometer apparatus.

\subsection{Optical density}

Growth estimation of bacteria was recorded by determination of optical density using colorimeter (Bio system BTS 320) at $670 \mathrm{~nm}$ of liquid cultures.

\subsection{Estimation of growth rate}

Growth rate was estimated according to the equation of Wahidin et al. (2013):

$\mu=\left[\ln \left(\mathrm{N}_{2}-\mathrm{N}_{1}\right)\right] /\left[\mathrm{t}_{2}-\mathrm{t}_{1}\right]$

Where, $\mathrm{N}_{1}$ and $\mathrm{N}_{2}$ are the cell number concentration (cell $\mathrm{mL}^{-1}$ ) at time $\mathrm{t}_{1}$ and $\mathrm{t}_{2}$

\subsection{Estimation of division rate}

The time required to duplicate the cell number: division rate $(K)$ was estimated according to the equation of Wahidin et al. (2013):

$K=\mu \div \ln 2$

\subsection{Removal efficiency of pollutants}

The removal efficiency of pollutants was expressed as:

Percent removal $\mathrm{W} \%=100 \%\left[\left(\mathrm{C}_{0}-\mathrm{C}_{\mathrm{i}}\right) / \mathrm{C}_{0}\right]$

Where, $\mathrm{C}_{0}$ and $\mathrm{C}_{\mathrm{i}}$ are defined as the mean values of pollutants concentration at initial time $\mathrm{t}_{0}$ and time $t_{i}$, respectively.

\section{RESULTS AND DISCUSSION}

\section{Pretreatment and characteristics of wastewater}

Wastewater was analyzed for a suite of chemical parameters commonly used to characterize chemical industrial water and are susceptible to affect algal growth (Table 1). The investigated samples of chemical industrial water contain high TDS (Over $1000 \mathrm{ppm}$ ), acidic pH (5.9), It was obviously that, wastewater samples contain high amount of nitrate (27.65 ppm) and phosphorus (967.1 ppm). TDS, $\mathrm{pH}$ and phosphorus were detected at levels exceeding the permissible one for the Egyptian drinking water standards. 
Bioremediation of some chemical pollutants from Fayoum industrial area, Egypt

Table 1. Characteristics of wastewater sample.

\begin{tabular}{|c|c|c|c|c|}
\hline No. & Parameter & Result & $\begin{array}{c}\text { EPA drinking water } \\
\text { standards }\end{array}$ & $\begin{array}{c}\text { Egyptian drinking } \\
\text { water standards }\end{array}$ \\
\hline $\mathbf{1}$ & Color & Colorless & 15 color units & - \\
\hline $\mathbf{2}$ & $\mathrm{pH}$ & 5.9 & $6.5-8.5$ & $6-9.5$ \\
\hline $\mathbf{3}$ & $\mathrm{TDS}$ & Over $1000 \mathrm{ppm}$ & $500 \mathrm{ppm}$ & $800 \mathrm{ppm}$ \\
\hline $\mathbf{4}$ & $\mathrm{NO}_{3}$ & $27.65 \mathrm{ppm}$ & $10 \mathrm{ppm}$ & - \\
\hline $\mathbf{5}$ & $\mathrm{P}$ & $967.1 \mathrm{ppm}$ & - & $25 \mathrm{ppm}$ \\
\hline $\mathbf{6}$ & $\mathrm{K}$ & $350.0 \mathrm{ppm}$ & - & - \\
\hline $\mathbf{7}$ & $\mathrm{Mg}$ & $50.0 \mathrm{ppm}$ & $0.05 \mathrm{ppm}$ & - \\
\hline $\mathbf{8}$ & $\mathrm{Ca}$ & $70.9 \mathrm{ppm}$ & - & - \\
\hline $\mathbf{9}$ & $\mathrm{Mn}$ & $2.76 \mathrm{ppm}$ & $0.05 \mathrm{ppm}$ & - \\
\hline $\mathbf{1 0}$ & $\mathrm{Fe}$ & $0.71 \mathrm{ppm}$ & $0.3 \mathrm{ppm}$ & - \\
\hline $\mathbf{1 1}$ & $\mathrm{Ni}$ & $150.0 \mathrm{ppb}$ & $1000 \mathrm{ppb}$ & - \\
\hline $\mathbf{1 2}$ & $\mathrm{Zn}$ & $72.0 \mathrm{ppb}$ & $5000 \mathrm{ppb}$ & - \\
\hline $\mathbf{1 3}$ & $\mathrm{Cr}$ & $11.6 \mathrm{ppb}$ & $100 \mathrm{ppb}$ & - \\
\hline $\mathbf{1 4}$ & $\mathrm{Cd}$ & $5.5 \mathrm{ppb}$ & $5.0 \mathrm{ppb}$ & \\
\hline
\end{tabular}

Seven metals were detected at the highest level. These were iron, magnesium, manganese, potassium, cadmium, zinc and calcium which are represent the major metals detected in the industrial wastewater. These metals were detected at levels exceeding the primary US Environmental Protection Agency (US EPA, 2012) drinking water standards and/or health advisories, whereas levels of nickel and chromium were under the permissible levels of these standards.

\section{Growth of microorganisms on serial dilutions of waste water}

\subsection{Bio treatment of wastewater using algae}

C. vulgaris grew on all serial dilutions of waste water, after inoculating the algae on the wastewater, chlorophyll-a content and cell counts were measured at regular intervals. The initial measured chlorophyll-a content and cell counts which represented baseline was $0.05 \mathrm{ppm}$ and $35 \times 10^{4}$ cell $\mathrm{mL}^{-1}$, respectively. $C$. vulgaris showed the highest growth at $100 \%$ wastewater on $40^{\text {th }}$ day of inoculation, in which cell counts of $838 \times 10^{4}$ cell $\mathrm{mL}^{-1}$ (Fig. 1) and chlorophyll-a content of $3.69 \mathrm{ppm}$ were detected (Fig. 2). One way analysis of variance indicated that the variation between sampling dates were highly significant $(\mathrm{P}=1.3 \mathrm{E}-14)$, whereas the variation between different dilutions showed slightly significant difference $(P=0.054)$. 
Khaled S.M. Foad et al.

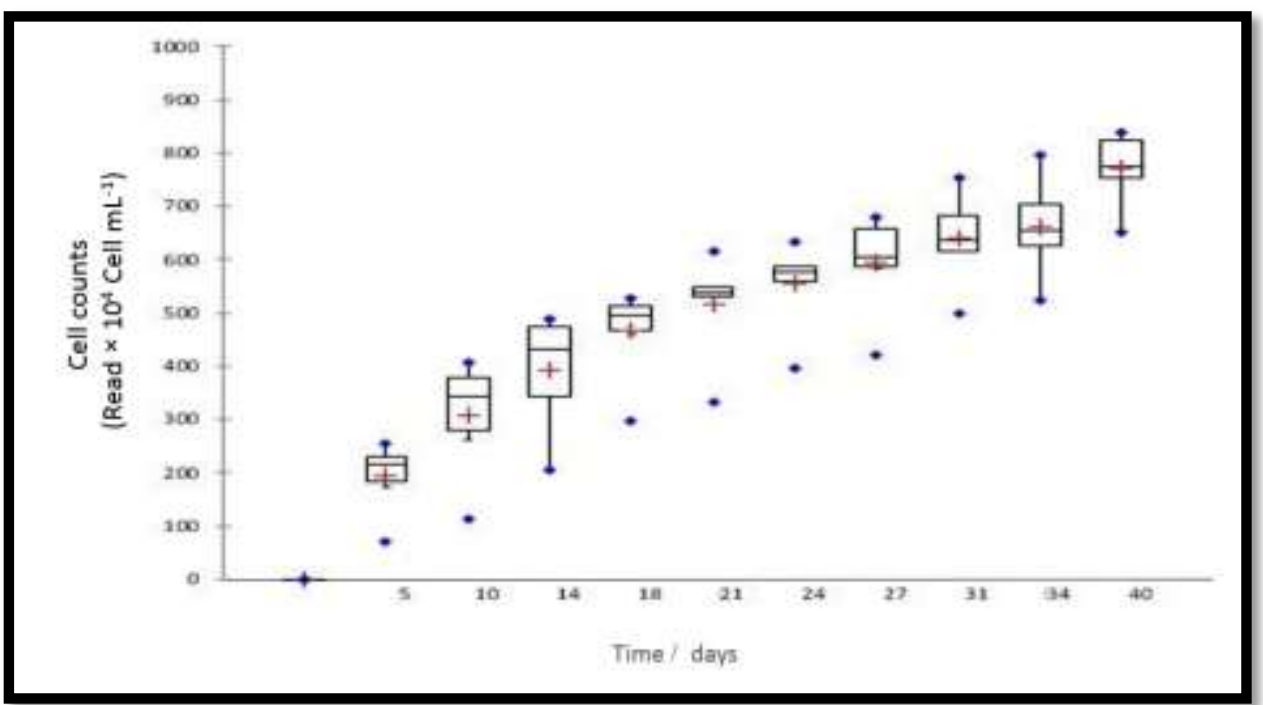

Fig. 1. Estimation of cell counts of $C$. vulgarison $100 \%$ waste water.

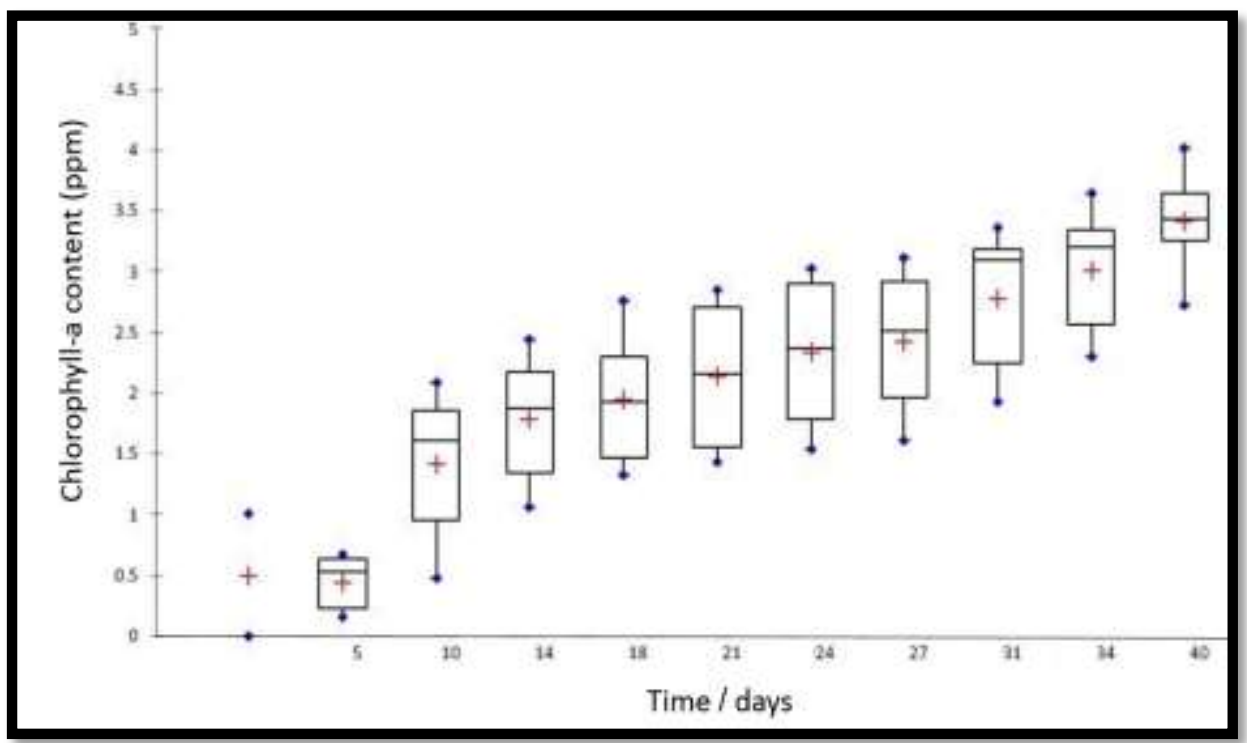

Fig. 2. Estimation of chlorophyll-a content of $C$. vulgaris on $100 \%$ waste water.

C. vulgaris showed both the highest and least growth rates of 1.51 and 0.63 at the control on days $27^{\text {th }}$ and $40^{\text {th }}$ of inoculation, respectively (Table 2). The highest average growth rate of 1.115 was measured at the control treatment whereas the least average of 0.993 was found at $60 \%$ dilution. One way analysis of variance indicated that the variation between sampling dates were highly significant $(P=6.12 \mathrm{E}-07)$, whereas the variation between different dilutions were non-significant $(\mathrm{P}=0.84)$. 
Bioremediation of some chemical pollutants from Fayoum industrial area, Egypt

Table 2. Estimation of growth rate of $C$. vulgaris on serial dilutions of waste water.

\begin{tabular}{|c|c|c|c|c|c|c|c|c|c|c|c|}
\hline \multirow{2}{*}{$\begin{array}{c}\text { Time } \\
\text { Dil. \% }\end{array}$} & \multicolumn{10}{|c|}{ Growth rate (G.R.) } \\
\cline { 2 - 13 } & $\mathbf{5}$ & $\mathbf{1 0}$ & $\mathbf{1 4}$ & $\mathbf{1 8}$ & $\mathbf{2 1}$ & $\mathbf{2 4}$ & $\mathbf{2 7}$ & $\mathbf{3 1}$ & $\mathbf{3 4}$ & $\mathbf{4 0}$ & Average \\
\hline Control & 1.038 & 0.95 & 1.158 & 0.99 & 1.25 & 1.32 & $\underline{1.51}$ & 1.072 & 1.23 & $\underline{0.63}$ & 1.115 \\
\hline $\mathbf{2 0} \%$ & 0.68 & 0.75 & 1.12 & 1.12 & 1.20 & 1.37 & 1.07 & 1.08 & 1.09 & 0.80 & 1.028 \\
\hline $\mathbf{4 0} \%$ & 0.97 & 0.89 & 0.99 & 1.24 & 1.42 & 1.06 & 1.13 & 0.84 & 0.80 & 0.80 & 1.014 \\
\hline $\mathbf{6 0} \%$ & 1.03 & 0.98 & 1.08 & 1.07 & 1.23 & 1.18 & 1.04 & 0.78 & 0.73 & 0.81 & 0.993 \\
\hline $\mathbf{8 0} \%$ & 1.05 & 1.00 & 1.14 & 0.85 & 1.18 & 1.13 & 1.13 & 0.95 & 1.07 & 0.77 & 1.027 \\
\hline $\mathbf{1 0 0} \%$ & 1.07 & 1.00 & 1.10 & 0.92 & 1.49 & 0.96 & 1.25 & 0.68 & 0.99 & 0.81 & 1.027 \\
\hline
\end{tabular}

C. vulgaris showed both the highest and least division rate of 2.18 and 0.92 at the control on days $27^{\text {th }}$ and $40^{\text {th }}$ of inoculation, respectively (Table 2). The highest average division rate of 1.61 was measured at the control treatment whereas the least average of 1.439 was found at $60 \%$ dilution. One way analysis of variance indicated that the variation between sampling dates were highly significant $(\mathrm{P}=7.57 \mathrm{E}-07)$, whereas the variation between different dilutions were non-significant $(\mathrm{P}=0.84)$.

Table 3. Estimation of division rate of $C$. vulgaris on serial dilutions of waste water.

\begin{tabular}{|c|c|c|c|c|c|c|c|c|c|c|c|}
\hline \multirow{2}{*}{$\begin{array}{c}\text { Time } \\
\text { Dil. \% }\end{array}$} & \multicolumn{10}{|c|}{ Division rate $(\boldsymbol{k})$} \\
\cline { 2 - 12 } Control & 1.49 & 1.37 & 1.67 & 1.43 & 1.80 & 1.91 & $\underline{\mathbf{2 . 1 8}}$ & 1.55 & 1.79 & $\underline{\mathbf{0 . 9 2}}$ & 1.611 \\
\hline $\mathbf{2 0} \%$ & 0.98 & 1.09 & 1.63 & 1.63 & 1.74 & 1.99 & 1.55 & 1.57 & 1.59 & 1.16 & 1.493 \\
\hline $\mathbf{4 0} \%$ & 1.42 & 1.29 & 1.43 & 1.80 & 2.05 & 1.53 & 1.64 & 1.22 & 1.15 & 1.16 & 1.469 \\
\hline $\mathbf{6 0} \%$ & 1.48 & 1.42 & 1.56 & 1.56 & 1.78 & 1.71 & 1.51 & 1.13 & 1.06 & 1.18 & 1.439 \\
\hline $\mathbf{8 0} \%$ & 1.52 & 1.45 & 1.65 & 1.23 & 1.71 & 1.64 & 1.64 & 1.37 & 1.55 & 1.12 & 1.488 \\
\hline $\mathbf{1 0 0} \%$ & 1.56 & 1.45 & 1.60 & 1.34 & 2.16 & 1.39 & 1.81 & 0.98 & 1.45 & 1.17 & 1.491 \\
\hline
\end{tabular}

At the $40^{\text {th }}$ days of the experiment, $C$. vulgaris reduced nitrate concentration from 27.65 to $13.42 \mathrm{ppm}$ by a percentage of $51.46 \%$, and reduced phosphorus concentration from 967.1 to $280.6 \mathrm{ppm}$ by a percentage of $70.98 \%$. Potassium concentration was reduced from 350 to 196.1 ppm by a percentage of $43.97 \%$, whereas magnesium concentration was reduced from 50 to 15.1 ppm by a percentage of $69.7 \%$.

Phosphorus is very important for cell growth and reproduction. Also, photosynthesis requires large amounts of proteins whish are synthesized by phosphorus-rich ribosomes (Agren 2004). Algae use three different bio-processes to transform $P$ into high energy organic compounds: phosphorylation at the substrate level, oxidative phosphorylation, and photophosphorylation (Sancho et al., 1997). According to Prescott (1968), green algae demand 
Khaled S.M. Foad et al.

more nitrogen and phosphorous than do many other species, and they can take up generous nitrogen when the phosphorous content is relatively high.

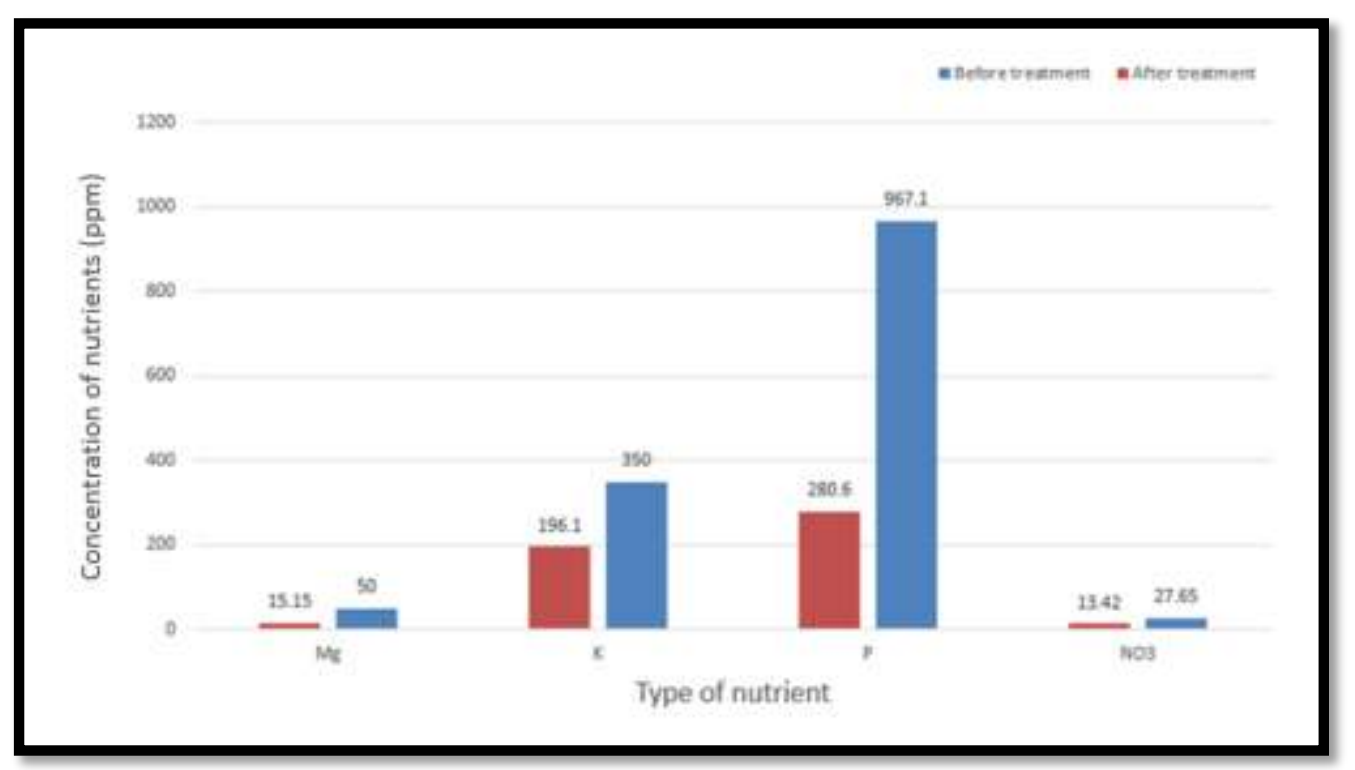

Fig..3. Removal efficiency of nutrients by $C$. vulgaris from $100 \%$ wastewater.

Nitrogen is an essential element of cells required for the biosynthesis of a large number of cell components including proteins, nucleic acids (RNA and DNA) and photosynthetic pigment. Chalivendra et al. (2013) mentioned that, the growth rate of algae increased with the increase in the nitrate concentration in the media.

The ability of algae to reduce other elements is that, potassium and magnesium play an important role in growth of $C$. vulgaris. Where, magnesium is important in photosynthesis as it is the central atom of chlorophyll molecules and it is also the cofactor of DNA polymerase which manages the cell division. Also, potassium is important for cell growth as it is a cofactor of several enzymes and plays important roles in protein synthesis and osmotic regulation. AbdelRaouf et al. (2012) cited several studies using C. vulgaris which reported 50.2\% - 86\% nitrogen removal and 70\% - 97.8\% phosphorus removal. Woertz et al. (2009) were able to remove $>98 \%$ of ammonium and $>96 \%$ of phosphorus with microalgae. Valderrama et al. (2002) used $C$. vulgaris to treat recalcitrant wastewater by reduction of ammonium ion (71.6\%) and phosphorus (28\%).

C. vulgaris exhibited the fastest growth with the greatest biomass yield, this biomass contain protein content of $29.04 \%$ and total phosphorus of $2.36 \%$. Standard deviations and averages of nitrogen, protein and phosphorus contents of $C$. vulgaris on $100 \%$ wastewater treatment on $40^{\text {th }}$ day were illustrated in Table (4). According to Richmond (2004), algae biomass typically contains $0.5 \%$ to $3.3 \%$ phosphorus content.

Table 4. $C$. vulgaris contents after $40^{\text {th }}$ day of $100 \%$ wastewater treatment.

\begin{tabular}{|c|c|c|c|}
\hline & Nitrogen & Protein & Total Phosphorus \\
\hline Average & $4.622 \% \pm 0.0024$ & $29.04 \% \pm 0.0017$ & $2.36 \% \pm 0.00027$ \\
\hline
\end{tabular}




\section{Bioremediation of some chemical pollutants from Fayoum industrial area, Egypt}

\subsection{Bio treatment of wastewater using Microccocu luteus}

Microccocu luteus grew slowly on all serial dilutions of waste water. After inoculating M. luteusin the wastewater, initial measured optical density which represented as baseline was found to be around 0.01. M. luteus showed the highest growth on $80 \%$ wastewater on $12^{\text {th }}$ day of inoculation, in which optical density was 0.329 , but its optical density $(0.207)$ was found on $100 \%$ wastewater.

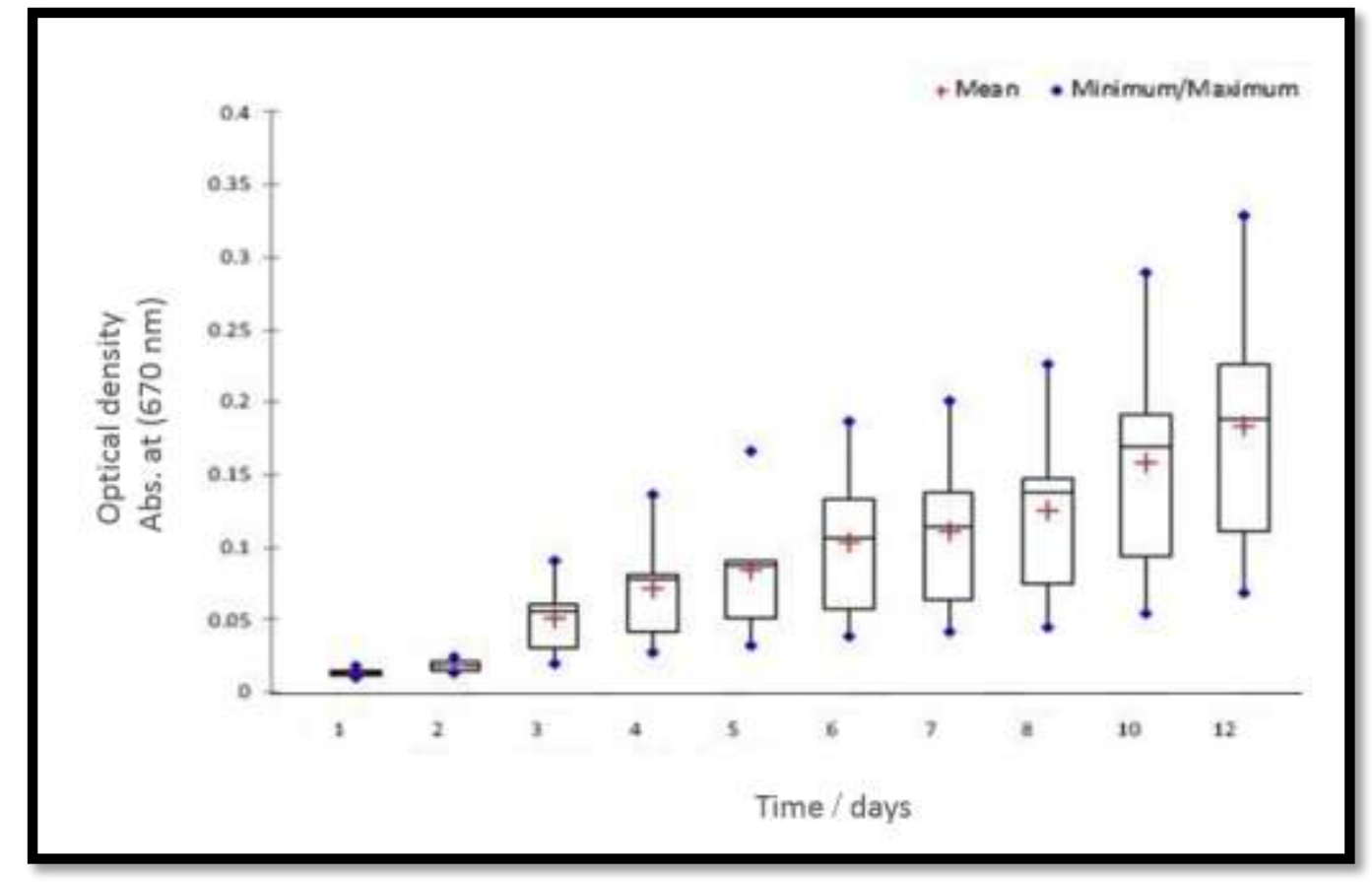

Fig.4. Estimation of optical densities of M. luteus on $100 \%$ waste water.

During $12^{\text {th }}$ day, $M$. luteus reduced nitrate concentration of waste water from 27.65 to $16.75 \mathrm{ppm}$ with a percentage of $39.4 \%$, and reduced phosphorus concentration from 967.1 to $675 \mathrm{ppm}$ with a percentage of $30.2 \%$. In the same time, potassium concentration was reduced from 350 to $244.2 \mathrm{ppm}$ with a percentage of $30.2 \%$, magnesium concentration was reduced from $50 \mathrm{ppm}$ to $35.5 \mathrm{ppm}$ by a percentage of $29 \%$. Zhuang et al. (2010) confirmed that, halophilic microorganisms play an important role in the biological treatment of saline wastewater as decontamination pathways of organic contaminants, heavy metals and nutrients. 


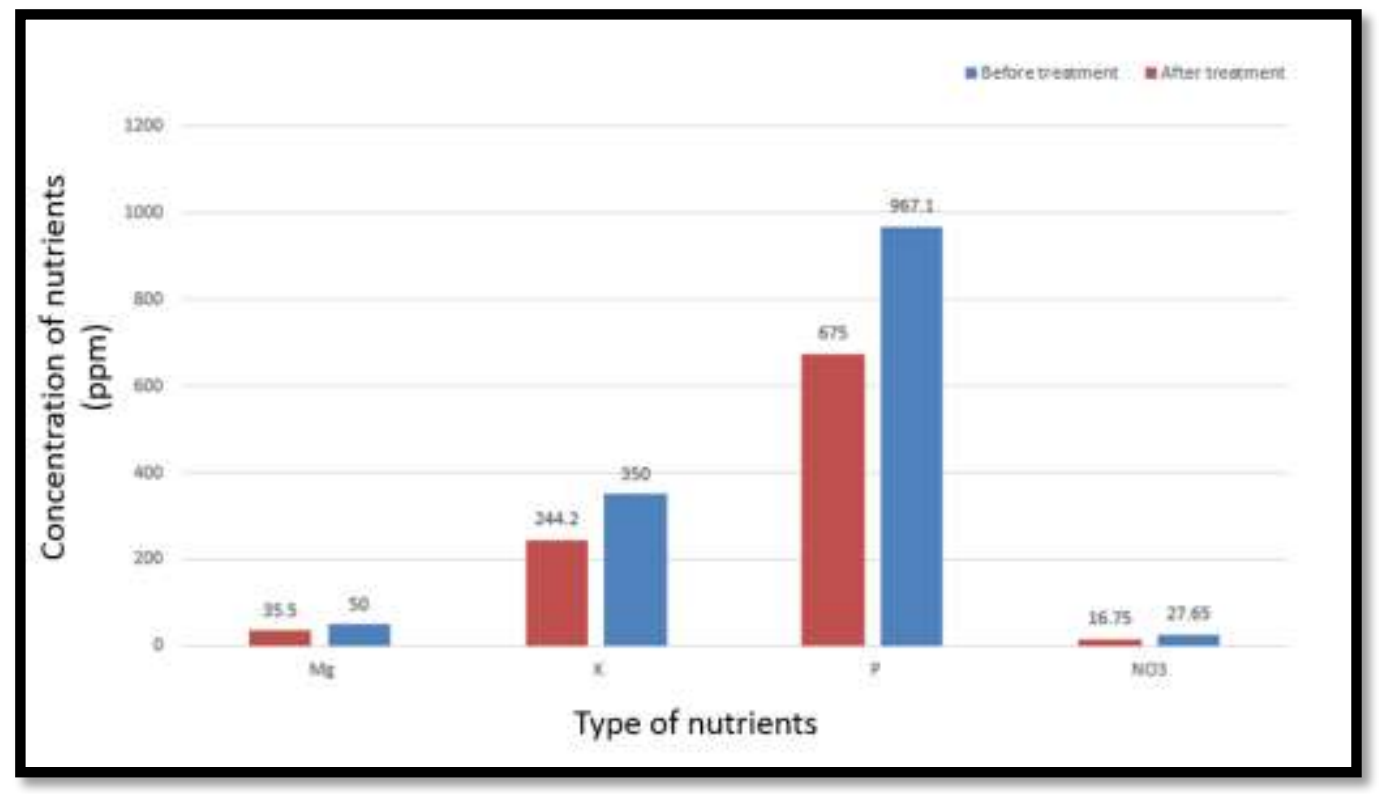

Fig. 5. Removal efficiency of nutrients byM. luteusfrom $80 \%$ wastewater.

\subsection{Bio treatment of wastewater using both $C$. vulgaris and M. luteus}

Regarding previous treatments, we designed this bio treatment by using both microorganisms that achieve high growth on wastewater (C. vulgaris and M. luteus) in ratio of $10 \mathrm{~mL}: 1 \mathrm{~mL}$, to activate each other and achieve the best bioremediation. Also, both grew on all serial dilutions of wastewater. After inoculation, initial measured cell counts of $C$. vulgaris which represented as baseline was $25 \times 10^{4}$ cell $\mathrm{mL}^{-1}$ and the initial optical density measured of M. luteus which represented as baseline was 0.03 at $670 \mathrm{~nm}$.

C. vulgaris showed the highest cell counts in $100 \%$ wastewater on $16^{\text {th }}$ day of inoculation, in which cell count was $1450 \times 10^{4}$ cell $\mathrm{mL}^{-1}$. It means that, growth of $C$. vulgaris was improved but $M$. luteus growth decreased into 0.081 if we compared it with optical density of single biotreatment of M.luteus in $100 \%$ wastewater. Some interpretations assumed that algal growth has been shown to be enhanced by growth promoting factors produced by bacteria in algal cultures (Fuentes et al., 2016).

On $16^{\text {th }}$ day, dual bio treatment reduced nitrate concentration from 27.65 to $9.55 \mathrm{ppm}$ with a percentage of $65.5 \%$, and reduced phosphorus concentration from 967.1 to $205.8 \mathrm{ppm}$ with a percentage of $78.7 \%$. Simultaneously, potassium concentration was reduced from 350 to $175.3 \mathrm{ppm}$ with a percentage of $49.9 \%$ and magnesium concentration was reduced from 50 to $10.6 \mathrm{ppm}$ with a percentage of $78.8 \%$. Hernandez (2006) reported that, combined treatment of microalgae and bacteria was capable of removing up to $72 \%$ of phosphorus from the wastewater. De-Bashan and Bashan (2010) used immobilized eukaryotic microalgae and several prokaryotic photosynthetic cyanobacteria, with emphasis on removing nutrients with the support of microalgae growth-promoting bacteria. 
Bioremediation of some chemical pollutants from Fayoum industrial area, Egypt

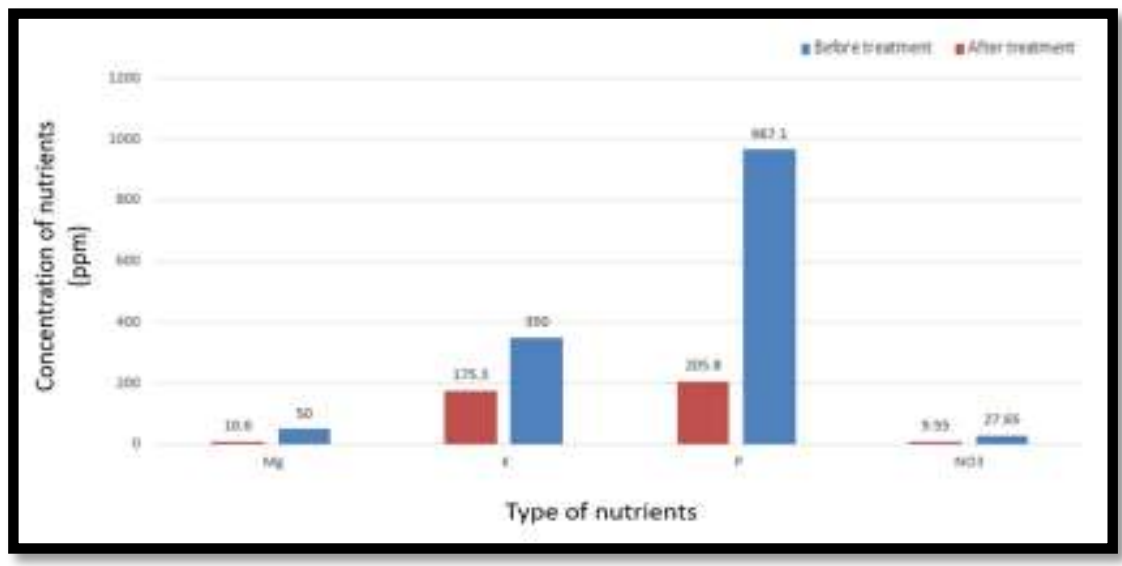

Fig. 6. Removal efficiency of nutrients from $100 \%$ wastewater usingdual bio treatment byC. vulgaris and M. luteus.

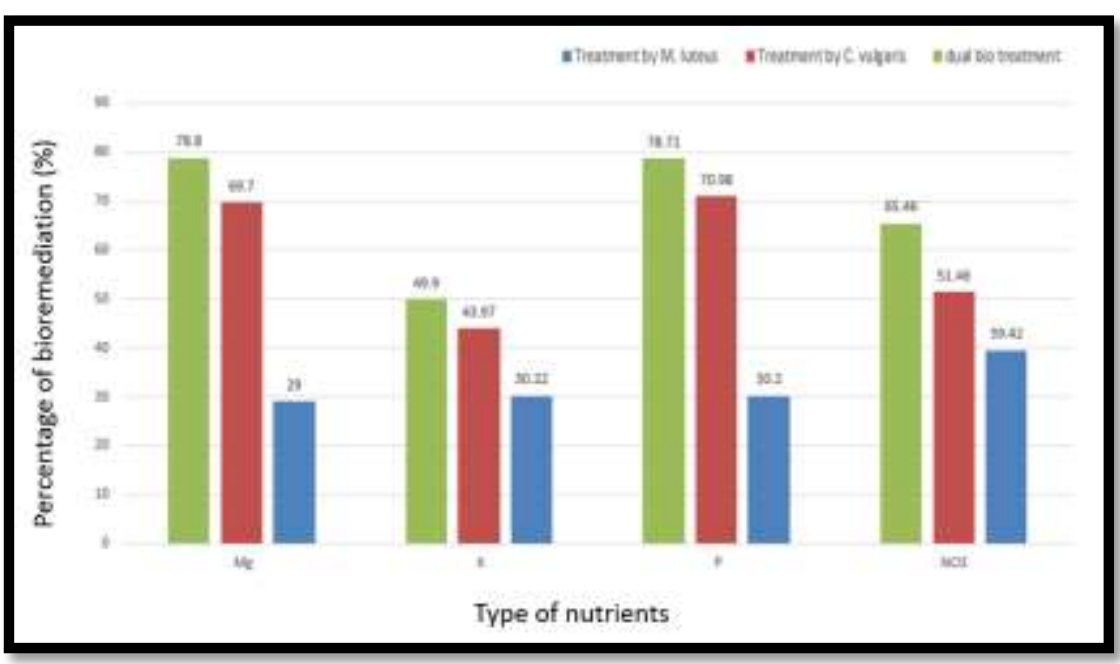

Fig. 7. Comparison between removal efficiency of nutrients in different bio treatment.

Table 5. Comparison of efficiency of bioremediation of $\mathrm{P}$ and $\mathrm{NO}_{3} \mathrm{using} C$. vulgaris among different researches.

\begin{tabular}{|c|c|c|}
\hline $\mathrm{NO}_{3}$ & $\mathbf{P}$ & Reference \\
\hline $\begin{array}{l}51.46 \% \\
77 \%\end{array}$ & $\begin{array}{l}70.98 \% \\
28 \% \\
>96 \% \\
33.1-33.3 \%\end{array}$ & $\begin{array}{l}\text { This study } \\
\text { Chamberlin (2002) } \\
\text { Valderrama et al. (2002) } \\
\text { Woertz et al. (2009) } \\
\text { Lim (2010) }\end{array}$ \\
\hline $50.2 \%-86 \%$ & $70 \%-97.8 \%$ & Abdel-Raouf et al. (2012) \\
\hline $90 \%$ & $62 \%$ & Chalivendra (2014) \\
\hline $96.4-99.4 \%$ & & Halfhide (2014) \\
\hline
\end{tabular}




\section{Khaled S.M. Foad et al.}

The phosphorus removal was much greater than those reported in many other studies using municipal wastewater (Valderrama et al., 2002, Lim, 2010 and Chalivendra, 2014), suggesting that the algae species used in this study is high phosphorus concentration tolerance. The results of this study revealed that total phosphorus contents in C. vulgaris was $2.36 \%$ which is in consistency with that reported by Richmond (2004), who conducted that algae biomass typically contains $0.5 \%$ to $3.3 \%$ phosphorus. Thus it is reasonable to conclude that a considerable part of phosphorus was removed by sedimentation and did not assimilate to algal biomass. The removal capacity of $\mathrm{NO}_{3}-\mathrm{N}$ is smaller than that reported by many other studies (Chamberlin, 2002,AbdelRaouf et al., 2012,Chalivendra, 2014 and Halfhide, 2014) suggesting that $\mathrm{NO}_{3}-\mathrm{Nis}$ not the only nitrogen form that can be assimilated by algae. Matusiak et al. (1976), Syrett, (1981), Barsanti and Gualtieri (2006) reported in their studies that, algae can assimilate NH4-N, nitrate, and simple organic nitrogen such as urea and amino acids in the wastewater, but the complicated organic nitrogen could not be directly used.

It was concluded from the present results that the best bio remediation of nitrate, phosphorus, potassium and magnesium from wastewater can be achieved by using dual bio treatment of $C$. vulgaris and $M$. luteus.

\section{REFERENCES}

Abdel-Raouf, N.; Al-Homaidan, A.A. and Ibraheem. I.B.M. (2012). Microalgae and wastewater treatment. Saudi J. Biological Sci., 19: 257-275.

Abraham, J. and Nanda, S. (2010). Evaluation of textile effluents before and after treatment with cyanobacteria. J. Industrial Pollution Control, 26:149-152.

Agren, G.I. (2004). The C: N: P stoichiometry of autotrophs - theory and observations. Ecol. Lett., 7:185-191.

Allen, M.M. and Stanier, R.Y. (1968). Growth and division of some unicellular blue-green algae. J. Gen. Microbiol.,51:199-202.

Chalivendra, S.C. (2014). Bioremediation of wastewater using microalgae. Ph.D Thesis, The School of Engineering, Univ. of Dayton, 212pp.

Chalivendra, S.C.; Lopez-casado, G.; Kumar, A.R. et al. (2013). Developmental onset of reproductive barriers and associated proteome changes in stigma/styles of Solanum pennellii. J. Experimental Bot., 64: 265 - 279.

Chamberlin J. (2002). Algal wastewater treatment and biofuel production: An assessment of measurement methods, and impact of nutrient availability and species composition. Ph.D. Thesis, University of California, 102pp.

De-Bashan, L.E. and Bashan, Y. (2010). Joint Immobilization of plant growth-promoting bacteria and green microalgae in Alginate beads as an experimental model for studying plant-bacterium Interactions. Appl. Environ. Microbiol.,74:6797-6802.

El-Sheekh, M.M.; Farghl, A.A.; Galal, H.R. and Bayoumi, H.S. (2016). Bioremediation of different types of polluted water using microalgae. Rendiconti Lincei, 27:401-410

Fuentes, J.L.; Garbayo, I.; Cuaresma, M.; Montero, Z.; González-del-Valle, M. and Vílchez, C. (2016). Impact of microalgae-bacteria interactions on the production of algal biomass and associated compounds. Marine Drugs, 14:100

Gonzalez, L.E.; Canizares, R.O. and Baena, S. (1997). Efficiency of ammonia and phosphorous removal from a Colombian agro industrial wastewater by the microalgae Chlorella vulgaris and Scenedesmus dimorphus. Bioresour. Technol., 60: 259-262. 


\section{Bioremediation of some chemical pollutants from Fayoum industrial area, Egypt}

Halfhide, T. (2014). Algae: Opportunities for biomass feedstock production, wastewater treatment and educational outreach. Ph.D Thesis, College of Engineering University of South Florida, 133pp.

Hameed, M.S.A. and Ebrahim, O.H. (2007). Biotechnological potential uses of immobilized algae. J.Agric. Biol., 9: 183-192.

Hernandez, J.P.; de-Bashan, L.E. and Bashan, Y. (2006). Starvation enhances phosphorus removal from wastewater by the microalga Chlorella spp. co-immobilized with Azospirillum brasilense. Enzyme and Microbial Technol., 38: 190-198.

Hughes, E.O.; Gorham, P.R. and Zehnder, A. (1958). Toxicity of a unialgal culture of Microcystis aeruginosa. Canadian J. Microbiol., 4: 225-236.

Kaoutar, B.C.; Sánchez, E. and Baghour, M. (2014). The role of algae in bioremediation of organic pollutants. Int. Res. J. Public and Environ. Health, 1: 19-32.

Karlander, E.P. and Krauss, R.W. (1996). Responses of heterotrophic cultures of Chlorella vulgaris Beyerink to darkness and light. II. Action spectrum and mechanism of the light requirement for heterotrophic growth. J. Plant Physiol., 41:7-14.

Karigar, C.S. and Rao, S.S. (2011). Role of microbial enzymes in the bioremediation of pollutants: A Review. Enzyme Res., 2011: 1-11

Kshirsagar, A.D. (2013). Bioremediation of wastewater by using microalgae: an experimental study. Int. J. Life Sc. Bt. and Pharm. Res., 2:339-346.

Larsdotter, K. (2006). Wastewater treatment with microalgae-A literature review. VATTEN, 62:31-38.

Lim, S.L.; Chu, W.L. and Phang, S.M. (2010). Use of Chlorella vulgaris for bioremediation of textile wastewater. Bioresour. Technol., 101: 7314-7322

Mehta, S.K. and Gaur, J.P. (2005). Use of algae for removing heavy metal ions from wastewater: progress and prospects. Crit. Rev. Biotechnol. ,25(3):113-52.

Metzner, H.; Rau, H. and Senger, H. (1965). Untersuchungen zur Synchronisierbarkeit einzelner Pigmentmangel-Mutanten von Chlorella. . Planta, 65:186.

Mitman, G.G. (2001). Bacterial effects and algal bioremediation by Chlorella ellipsoidea gerneck of the Berkeley Pit Lake System. J. Phycol.,37: 36

Olguín, E.J. (2012). Dual purpose microalgae-bacteria-based systems that treat wastewater and produce biodiesel and chemical products within a biorefinery. Biotechnol. Adv., 30: 103146.

Prabha, Y.; Soni, S.K.; Gupta, S. and Sonal, A. (2016). Potential of algae in bioremediation of wastewater. Int. J. Curr. Microbiol. App. Sci., 5: 693-700.

Prescott, G.W. (1968). The algae-A review: Boston, Houghton Mifflin Company, p436.

Priyadarshani, I.; Sahu, D. and Rath, B. (2011). Microalgae bioremediation: current practices and perspectives. J. Biochem. Technol., 3: 299-304.

Raposo, M.F. de J.; Susana E.O.; Paula, M.C.; Narcisa, M.B. and Rui, M.M. (2010). On the utilization of microalgae for Brewery effluent treatment and possible applications of the produced biomass. J. Inst. Brew., 116: 285-292.

Richmond, A. (2004). Biological principles of mass cultivation. Biotechnol. Appl. Phycol., 2004:125-77

Safonova, E.; Kvitko, K.V.; Iankevitch, M.I. and Reisser, W. (2004). Biotreatment of industrial wastewater by selected algal-bacterial Consortia. Engineering in Life Sciences 4:347 - 353 


\section{Khaled S.M. Foad et al.}

Sambrook, J.; Fritschi, E.F. and Maniatis, T. (1989). Molecular cloning: a laboratory manual, Cold Spring Harbor Laboratory Press, New York.

Sancho, E.; Ferrando, M.D. and Andrev, E. (1997). Sub lethal effects of an organophosphate insecticide on the European eel, Anguilla anguilla. Ecotoxicol. Environ. Saf., 36: 57-65

Sharma, G.K. and Khan, S.A. (2013). Bioremediation of sewage wastewater using selective algae for manure production. Int. J. Environ. Eng. Manag., 4: 573-580

Shi, J. (2009). Removal of nitrogen and phosphorus from municipal wastewater using microalgae immobilized on twin-layer system. Ph.D. Thesis, University of Cologne.

Tam, N.F.Y.; Lau, P.S. and Wong, Y.S. (1994). Wastewater inorganic N and P removal by immobilized Chlorella vulgaris. Wat. Sci. Technol., 30: 369-74

Tarlan, E.; Dilek, F.B. and Yetis, U. (2002). Effectiveness of algae in treatment of a wood-based pulp and paper industry wastewater. Bioresour. Technol., 84: 1-5.

Travieso, L.; Benitez, F. and Dupeiron, R. (1992). Sewage treatment using immobilized microalgae. Bioresour. Technol., 40: 183-187.

US EPA (2012). Drinking Water Standards and Health Advisories, Washington; D.C., USA.

Valderrama, L.T.; Del Campo, C.M.; Rodriguez. C.M.; Luz, E. and Bashan, Y. (2002). Treatment of recalcitrant wastewater from ethanol and citric acid production using the microalga Chlorella vulgaris and the macrophyte Lemna minuscula. Water Res., 36:41854192.

Validi, M. (2001). Bioremediation. An Overview. Pure Appl. Chem., 73: 1163 -1172.

Wahidin, S.; A. Idris, and S.R.M. Shaleh. (2013). The influence of light intensity and photoperiodon the growth and lipid content of microalgae Nannochloropsis sp. Bioresource Technol., 129(0): 7-11.

Woertz, I.; Feffer, A.; Lundquist, T. and Nelson, Y. (2009). Algae grown on dairy and municipal wastewater for simultaneous nutrient removal and lipid production for biofuel feedstock. J. Environ. Eng., 135: 1115-1122.

Zhuang, X.; Han, Z.; Bai, Z.; Zhuang, G. and Shim, H. (2010). Progress in decontamination by halophilic microorganisms in saline wastewater and soil. Environ. Pollut., 158, 11191126.

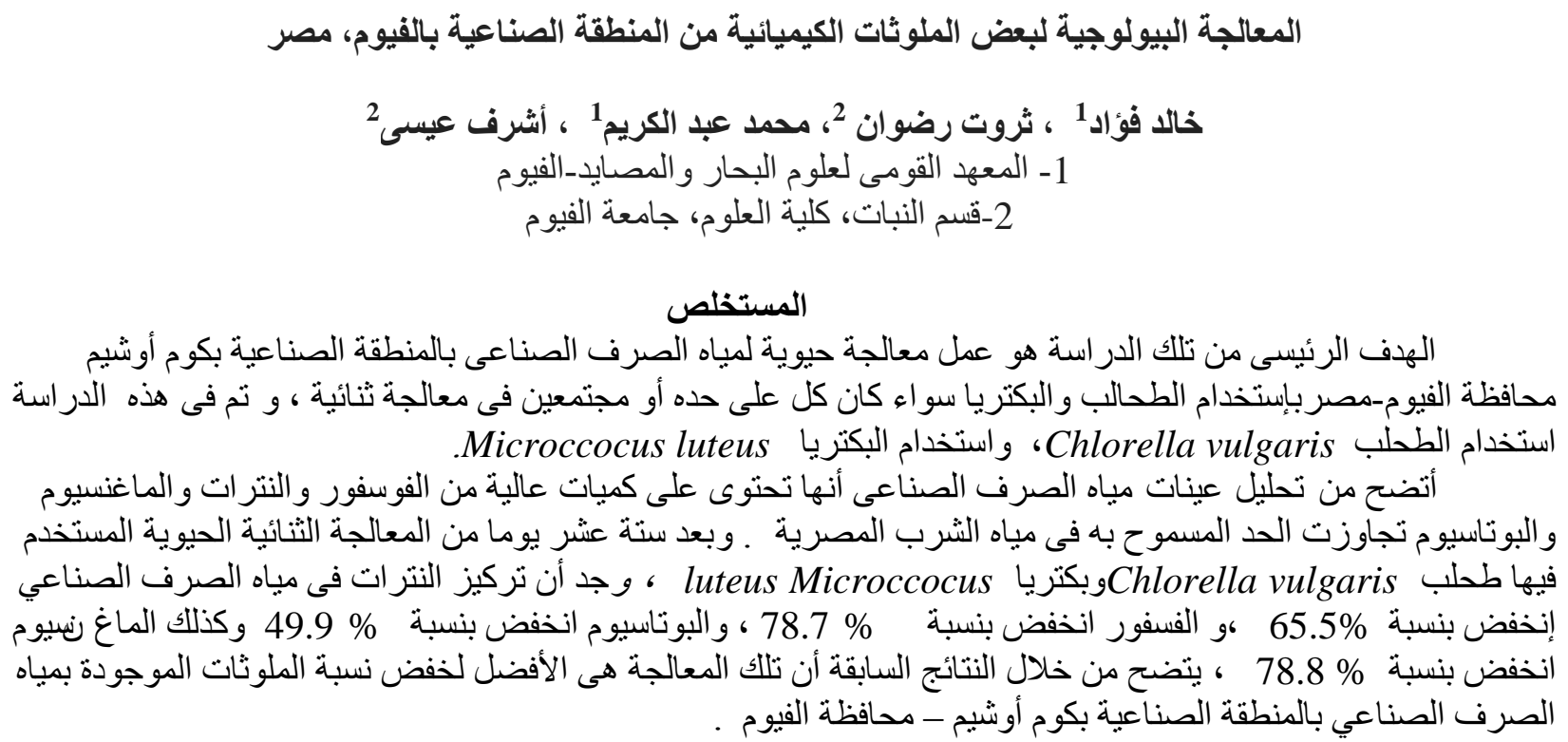

